Arab Univ. J. Agric. Sci., Ain Shams Univ., Cairo, Egypt 28(1), 253-263, 2020

Website: http://ajs.journals.ekb.eg

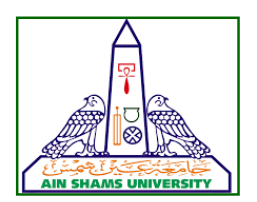

\title{
IMPACT OF PINK PIGMENTED FACULTATIVE METHYLOTROPHIC BACTERIA AS A BIO-STIMULANT ON GROWTH, HERB YIELD AND VOLATILE OIL ATTRIBUTES OF ROSEMARY (Rosmarinus officinalis L.) PLANT
}

\author{
Doaa Soliman ${ }^{1}$, Hosni ${ }^{1}$ A.M., Abdelhamid ${ }^{1 *}$ A.N. and Mona A. Mohammed ${ }^{2}$ \\ 1- Horticulture Dept., Fac. of Agric., Ain Shams Univ., P.O. Box 68, Hadayek Shoubra 11241, \\ Cairo, Egypt \\ 2- Pharmaceutical and Pharmacy Research Division, National Research Center, Giza, Egypt
}

${ }^{*}$ Corresponding author: nazmy604@yahoo.com

Received 9 April, 2020

Accepted 12 April, 2020

\section{ABSTRACT}

The effect of Pink Pigmented Facultative Methylotrophic (PPFM) bacteria as a bio-stimulant on vegetative growth, macro-nutrient elements (N,P and $\mathrm{K}$ ) contents, chemical constituents and volatile oil percentage and components in rosemary plant (Rosmarinus officinalis L.) were studied during 2018 and 2019 seasons. Plant height $(\mathrm{cm})$, number of lateral branches/plant, herb fresh \& dry weights and root fresh \& dry weights of rosemary plant were all greatly affected with all applied treatments of PPFM when compared with the control. The hugest effect was recorded by $1 \%$ PPFM bacteria spraying in both studied seasons. However, no significant effect was recorded due to PPFM applied treatments on $\mathrm{P} \%$. Highest values of total carbohydrates were recorded by both 1 and $3 \%$. PPFM bacteria spraying in both studied seasons. Whereas, the highest values of $\mathrm{C} / \mathrm{N}$ ratios were obtained with $3 \%$ PPFM in first season and $1 \%$ PPFM in the second one. A substantial effect from PPFM bacteria spraying was observed through its effect on reducing the level of $\mathrm{NO}_{3}$ and $\mathrm{NO}_{2}$ in rosemary herb when compared with the control. In any case, 3\% of PPFM bacteria spraying was more effective than other treatments in recording the least values of $\mathrm{NO}_{3}$ and $\mathrm{NO}_{2}$ in first season compared to the control. Volatile oil \% was enormously increased with 3\% PPFM bacteria spraying in both studied seasons than other treatments or control. The main components of volatile oil of rosemary plant were Camphor, Eucalyptol, Verbenone, Borneol, Pinene, Pinanone, Bornyl ac- etate and Camphene. The treatments of PPFM bacteria spraying immensely stimulated the component $\%$ in volatile oil of rosemary herb than in the control. It could be concluded that the application of PPFM bacteria as foliar spraying in rosemary plant production had many advantages especially reducing $\mathrm{NO}_{3}$ and $\mathrm{NO}_{2}$ levels and increasing volatile oil \% and volatile oil fractions not to mention it increased the percent of active ingredients.

Keywords: PPFM bacteria, Rosemary plant, NPK, Carbohydrate, $\mathrm{NO}_{3}, \mathrm{NO}_{2}$, Volatile oil, Herb

\section{INTRODUCTION}

The present work is adapted to evaluate one of the most important medicinal and aromatic plant i.e. rosemary plant (Rosemarinus officinalis L.) and maximize quality and quantity of this plant. Rosemary, one of many species follow lamiaceae family, is a woody herbaceous plant originated from the Mediterranean region. Many places in southeast Spain process and imported rosemary herb, as a singular spice trade used for many purpose such as antioxidant protection (Cuvelier et al 1996).

The extracts of the rosemary plant treat many diseases as a hepatic protective possibility (Raskovic et al 2014) minimizing the rate of Alzheimer's illness (Habtemariam, 2016) and its antiangiogenic effect (Kayashima and Matsubara, 2012). On the other side, ground rosemary herb could be used as a food protection due to its ability in preventing all types of contamination either oxidation or microbial effect (Nieto et al 2012). However, rosemary dry herb is beneficial in reducing 
synthetic antioxidants in different commodities where it has many techniques help the consumers in avoiding many stomach troubles.

For these beneficial effects for rosemary herb, it widely used as a spice and medicinal traits around the world and cultivated for a long time. In ancient Egypt, Mesopotamia, China and India rosemary herbs employed as a aromatic and medicinal, cooking and cosmetic materials. The main purpose of rosemary cultivation is volatile oil production which extracted from the herb of plant at flower bud stage, which considered the suitable period for high quality and quantity volatile oil production. (Raskovic et al 2014).

Also, the herbs of rosemary are used as a good taste spice and the oil is applied in perfume and saver industries and aromatic curing for many diseases (Mizrahi et al 1991). Many researchers concluded that the volatile oil of rosemary has many advantages (Wada et al 2004), antifungal \& bacteria and antitumor material (Pintore et al 2002) and used in conventional medicine for chore tics and many human diseases (Slamenova et al 2002). Also, a great effect to volatile oil of rosemary herb was also documented by (Socaci et al 2008) who mentioned that it enhance the blood circulation of the limbs, antirheumatic effect and relieve the pain the pain of neuralgic .

Pink-pigmented facultative methylotrophs (PPFMs) bacteria is isolated from many material, particularly from leaf surfaces (Corpe and Rheem, 1989), and proved affiliation with pretty 70 plant species including many economic plants (Corpe, 1985 and Holland and Polacco, 1994) which make them exciting as potential agents surviving and helping plant growth and / or suppressing disease.

Certain isolates are known to release auxins (Doronina et al 2002), cytokinins (Koenig et al 2002) and vitamin B12 (Basile et al 1985). Interactions with the plant nitrogen metabolism mediated by using bacterial urease and consequently the feasible position of this in seed germination body structure have additionally been described (Holland and Polacco, 1994). Bacteria of the genus Methylobacterium had been observed to nodulate legumes of the genus Crotalaria (Sy et al 2001) which indicating robust plant bacteria interactions.

As for the PPFM populations on crop plant life or on medicinal and fragrant plant life which include their dynamics, available data are contradictory and fragmentary. The available previews studies on PPFM populations became discovered on clover field crop which are described on a two-sampling base and higher levels of PPFMs associated with leaves had been detected at some stage in the summer season months as compared with the populace detected during early spring and late fall (Corpe, 1985).

In another constrained survey dutch clover samples were collected all through 1.5 months and no population changes befell in the course of this era (Corpe and Rheem, 1989). On the opposite hand, Hirano and Upper, (1991) at some point of a 1.5month survey on snap found populace variations for the duration of the considered sampling period.

The phyllosphere harbors are a various organization of microorganisms and therefore the interaction between the plant and microbes greatly affect the physiological activities of the plant. PPFMs are the prime population of the phyllosphere area of a good kind of plant species (Raja et al 2008 \& Ochsner et al 2015). From this view, this work becomes designed to the effect of PPFM as a bio-stimulant on best of rosemary plant. Generally, PPFMs microorganism companies are labeled as $\alpha$-proteobacteria, capable of growing even on single carbon compounds like methanol and methylamine (Madhaiyan et al 2012). Many types of Methylobacterium sp. had synergistic effect of the host plant by way of producing indole ethanoic acid (IAA).

They synthesize a range of auxins and cytokinins which are used by the host plant life for growth and development additionally increasing many active ingredient substances. Many researchers pronounced the position of PPFMs in enhancing plant increase, seed germination, seed vigor index, plant yield, lively materials and systemic resistance of the plant (Mizuno et al 2013). Methylotrophic micro organism on plant floor either as a spraying remedy or naturally discovered act throughout a symbiotic courting with the host plants as they get benefited via methanol emitted from flora as a by-product of pectin degradation (Tani et al., 2012).

Thus, the intention of this study became to evaluate the impact of PPFM microorganism as a biostimulant on growth, herb yield, chemical components, volatile oil content and important oil additives of rosemary (Rosmarinus officinalis L.) plant.

\section{MATERIALS AND METHODS}

This study was done during the two successive seasons of 2018 and 2019 to evaluate the impact of foliar spray of pink pigmented facultative methylotrophic bacteria (PPFM) on vegetative growth, chemical components, volatile oil content and volatile oil components of rosemary (Rosemarinus officinalus L.) plant. 
Impact of pink pigmented facultative methylotrophic bacteria as a bio-stimulant on growth, 255 herb yield and volatile oil attributes of rosemary (Rosmarinus officinalis $I$.) plant

The experiment took place in the Ornamental Nursery, Faculty of Agriculture, Ain Shams University, Cairo, Egypt. The rosemary transplants were sown on the first week of March in both studied seasons in $35 \mathrm{~cm}$ diameter plastic pots filled with peat moss and sand (1:1), one seedling for each pot. The seedlings selected were uniform in shape and exposed to all horticultural practices including irrigation, fertilization and pest management as recommended in this respect.

The solution of PPFM ( $10^{9} \mathrm{CFU} / \mathrm{ml}$.) bacteria were sprayed 4 times beginning from the first of May in both studied seasons, one spray every 15 days. Pots were coordinated in a complete randomized block design where 4 treatments of PPFM bacteria were used in 4 replicates and each replicate contained 4 pots $=64$ rosemary plants for each season.

PPFM bacteria solution was obtained and donated from the Microbial Inoculants Center, Faculty of Agriculture, Ain Shams University. The concentration of PPFM was $10^{\circ} \mathrm{CFU} / \mathrm{ml}$. (colonies forming unit). The following four treatments were created :

1- Control (sprayed with distilled water)

2- $1 \%$ PPFM concentration (10 ml/liter)

3- $2 \%$ PPFM concentration ( $20 \mathrm{ml} /$ liter)

4- $3 \%$ PPFM concentration ( $30 \mathrm{ml} /$ liter)

At first of September in each season, the following data were recorded:

\section{1- Vegetative growth parameters}

Plant height $(\mathrm{cm})$ from $5 \mathrm{~cm}$ of pot surface to maximum height, number of lateral branches / plant , herb fresh \& dry weights/ plant (g) and root fresh \& dry weights/ plant $(\mathrm{g})$.

\section{2- Macronutrient contents (N, P and $K \%$ )}

Nitrogen was determined according to Guebel, et al (1991), phosphorus was determined as stated by Bringham (1982) and potassium in a manner corresponding to Westerman (1990).

\section{3- Chemical constituents}

Total carbohydrates were determined as $\mathrm{g} / 100$ dry weight of herb according to the method described by A.O.A.C (2005). C/N ratio was calculated by separator of total nitrogen by total carbohydrates. Nitrate $\left(\mathrm{NO}_{3}\right)$ and Nitrite $\left(\mathrm{NO}_{2}\right)$ contents were measured as method reported by A.O.A.C. (2012).
Volatile oil \% was determined by fresh herb extracting proma water distillation method laid down by Novak et al (2002). The amount of volatile oil \% was evaluted according to the procedure provided by Charles and Simon (1990)

\section{4- Volatile oil components}

Chemical constituents of volatile oil of the herb were analysed using the Trace GC Ultra/Mass spectrophotometer ISQ (Thermo Scientific, GC/MS) apparatus to determine their main components (Charles and Simon, 1990).

\section{Statistical analysis}

Results were statistically analyzed using the analysis of variance (ANOVA) as described by Snedecor and Cochran (1990). The method of Duncan's multiple range tests was applied for the comparison between means as be prescribed by Waller and Duncan (1969).

\section{RESULTS AND DISCUSSION}

\section{1- Vegetative growth parameters}

Data in Tables (1, 2 and 3) show the effect of foliar spray of pink pigmented faculative methylotrophic bacteria (PPFM) on vegetative growth parameters of rosemary (Rosemarinus officinalis L.) plant.

Plant height was considerably affected with all used concentrations of PPFM bacteria spraying than in the control. The greatest increase was obtained with $1 \%$ concentration followed by $2 \%$ and $3 \%$, in first season. The same trend of results were also found in the second season, but $2 \%$ and $3 \%$ PPFM bacteria spraying were similar in their effect on plant height. An evident increase in number of lateral branches in rosemary plant was obtained due to spraying of PPFM bacteria when compared to the control. Also, $1 \%$ concentration of PPFM bacteria recorded the highest values of number of lateral branches than $2 \%$ or $3 \%$ treatments. Significant differences between the used treatments of PPFM existed in both seasons except in the first season where $3 \%$ of PPFM was similar to control. 
Table 1. Effect of PPFM bacteria spraying as a biostimulant on plant height and number of lateral branches in rosemary (Rosmarinus officinalis L.) plant, during 2018 and 2019 seasons.

\begin{tabular}{|c|c|c|c|c|}
\hline \multirow{2}{*}{ Treatments } & \multicolumn{2}{|c|}{ Plant height (cm) } & \multicolumn{2}{c|}{$\begin{array}{c}\text { No. of lateral } \\
\text { branches / plant }\end{array}$} \\
\cline { 2 - 5 } & $\begin{array}{c}\mathbf{2 0 1 8} \\
\text { season }\end{array}$ & $\begin{array}{c}2019 \\
\text { season }\end{array}$ & $\begin{array}{c}\mathbf{2 0 1 8} \\
\text { season }\end{array}$ & $\begin{array}{c}\mathbf{2 0 1 9} \\
\text { season }\end{array}$ \\
\hline Control & $41.19 \mathrm{~d}$ & $41.15 \mathrm{c}$ & $19.50 \mathrm{c}$ & $24.63 \mathrm{~d}$ \\
1 \% PPFM & $48.13 \mathrm{a}$ & $56.12 \mathrm{a}$ & $28.57 \mathrm{a}$ & $31.13 \mathrm{a}$ \\
2 \% PPFM & $43.32 \mathrm{~b}$ & $46.93 \mathrm{~b}$ & $21.82 \mathrm{~b}$ & $30.50 \mathrm{~b}$ \\
3 \% PPFM & $42.00 \mathrm{c}$ & $46.24 \mathrm{~b}$ & $19.63 \mathrm{c}$ & $29.56 \mathrm{c}$ \\
\hline
\end{tabular}

- PPFM = Pink Pigmented Facultative Methylotrophic bacteria.

- Values followed by the same letter (s) are not significantly different at $5 \%$ level (Waller and Duncan, 1969).

Table 2. Effect of PPFM bacteria spraying as a biostimulant on herb fresh weight and herb dry weight in rosemary (Rosmarinus officinalis L.) plant, during 2018 and 2019 seasons.

\begin{tabular}{|c|c|c|c|c|}
\hline \multirow{2}{*}{ Treatments } & \multicolumn{2}{|c|}{$\begin{array}{c}\text { Herb fresh weight } \\
(\mathbf{g})\end{array}$} & \multicolumn{2}{c|}{$\begin{array}{c}\text { Herb dry weight } \\
(\mathbf{g})\end{array}$} \\
\cline { 2 - 5 } & $\begin{array}{c}\mathbf{2 0 1 8} \\
\text { season }\end{array}$ & $\begin{array}{c}\mathbf{2 0 1 9} \\
\text { season }\end{array}$ & $\begin{array}{c}\mathbf{2 0 1 8} \\
\text { season }\end{array}$ & $\begin{array}{c}\mathbf{2 0 1 9} \\
\text { season }\end{array}$ \\
\hline Control & $74.75 \mathrm{~d}$ & $59.33 \mathrm{~d}$ & $20.75 \mathrm{c}$ & $15.82 \mathrm{~d}$ \\
$1 \%$ PPFM & $94.94 \mathrm{a}$ & $83.12 \mathrm{a}$ & $25.44 \mathrm{a}$ & $26.36 \mathrm{a}$ \\
2 \% PPFM & $85.00 \mathrm{~b}$ & $75.67 \mathrm{~b}$ & $23.13 \mathrm{~b}$ & $19.99 \mathrm{~b}$ \\
3 \% PPFM & $83.81 \mathrm{c}$ & $63.15 \mathrm{c}$ & $20.75 \mathrm{c}$ & $19.02 \mathrm{c}$ \\
\hline
\end{tabular}

- PPFM = Pink Pigmented Facultative Methylotrophic bacteria.

- Values followed by the same letter (s) are not significantly different at $5 \%$ level. (Waller and Duncan, 1969).

Table 3. Effect of PPFM bacteria spraying as a biostimulant on root fresh weight and root dry weight in rosemary (Rosmarinus officinalis L.) plant, during 2018 and 2019 seasons.

\begin{tabular}{|c|c|c|c|c|}
\hline \multirow{2}{*}{ Treatments } & \multicolumn{2}{|c|}{$\begin{array}{c}\text { Root fresh weight } \\
(\mathbf{g})\end{array}$} & \multicolumn{2}{c|}{$\begin{array}{c}\text { Root dry weight } \\
\text { (g) }\end{array}$} \\
\cline { 2 - 5 } & $\begin{array}{c}\mathbf{2 0 1 8} \\
\text { season }\end{array}$ & $\begin{array}{c}\mathbf{2 0 1 9} \\
\text { season }\end{array}$ & $\begin{array}{c}\mathbf{2 0 1 8} \\
\text { season }\end{array}$ & $\begin{array}{c}\mathbf{2 0 1 9} \\
\text { season }\end{array}$ \\
\hline Control & $26.97 \mathrm{~d}$ & $21.85 \mathrm{c}$ & $14.60 \mathrm{c}$ & $11.11 \mathrm{~d}$ \\
$1 \%$ PPFM & $34.28 \mathrm{a}$ & $33.27 \mathrm{a}$ & $18.11 \mathrm{a}$ & $17.59 \mathrm{a}$ \\
$2 \%$ PPFM & $30.40 \mathrm{~b}$ & $28.43 \mathrm{~b}$ & $15.24 \mathrm{~b}$ & $14.51 \mathrm{~b}$ \\
$3 \%$ PPFM & $28.69 \mathrm{c}$ & $22.17 \mathrm{c}$ & $15.13 \mathrm{~b}$ & $12.27 \mathrm{c}$ \\
\hline
\end{tabular}

- PPFM = Pink Pigmented Facultative Methylotrophic bacteria.

- Values followed by the same letter (s) are not significantly different at $5 \%$ level. (Waller and Duncan, 1969).
Herb fresh and dry weight values of rosemary plant showed that all PPFM bacteria spraying treatments greatly increased their values than in the control. However, $1 \%$ PPFM was superior than 2 or $3 \%$ treatments in increasing values of fresh and dry herbs. Significant differences were clear either between the different treatments or between the treatments and control.

Root fresh and dry weights of rosemary plant were largely affected with PPFM bacteria spraying as a bio-stimulant than control. The effect was correlated with the used concentrations where the treatment of $1 \%$ PPFM was superior in this regard followed by $2 \%$ whereas $3 \%$ came last.

The obtained facts are similar to those explained through Holland (1997) who referred to that PPFMs Spp as microorganism symbionts of plants, devour plant waste products and release metabolite products useful to the plant which has notable influence on seedling expansion by way of generating plant growth regulators like zeatin andassociated cytokinins and auxins and modify agronomic tendencies like branching, seedlings energy rooting and heat/ bloodless tolerance. Also, on this respect, Madhaiyan et al (2006) discovered that Methylobacterium, as plant symbionts, has useful consequences on dealt with plant boom through direct or indirect mechanisms, which include production of enzymes and secretion of compounds concerned in bio control or is order suppression.

Similar outcomes which were in a agreement as accomplished have been also observed by thus found by Meena et al (2012) who mentioned that foliar application of PPFM appreciably advanced root and shoot length and number of leaves in tomato vegetation. Also, Madhaiyan et al (2012) stated that utility of PPFM as foliar spray notably expanded plant top and plant dry weight in cotton and sugarcane. They said that thus extraordinary results attributed to the growth of overall cytokinins and PPFM population with act as a bio-stimulant component.

Clearly, PPFM bacteria is a tremendously diversified institution of microorganisms abundantly gift at the phyllosphere vicinity of several plant species together with medicinal and fragrant vegetation and enhance the plant increase with the aid of producing a wide type of phytohormones (Meena et al 2012 and Mizuno et al 2013). The promoting impact of PPFM bacteria on vegetative boom was also mentioned in many flowers (Gashti et al 2014). The mode of action for the promoting effect might be ex- 
Impact of pink pigmented facultative methylotrophic bacteria as a bio-stimulant on growth, 257 herb yield and volatile oil attributes of rosemary (Rosmarinus officinalis $I$.) plant

plained by way of the truth that PPFM microorganism have the potential to provide some growth regulators which include auxins and cytokinins (Lee et al 2006 and Nadali et al 2010).

These increase promoters have initial first rate outcomes on enhancing mobile division and cell enlargement. Generally, it may be concluded that Methylobacterium is one such microbe that acts as little farmers, nurturing and protecting plants at each stage (Holland et al 2002).

\section{2- Macronutrients contents (N, P and K\%)}

Data in Table (4) show that spraying of PPFM as a bio-stimulant on rosemary plant greatly improved leaves contents of $\mathrm{N}, \mathrm{P}$ and $\mathrm{K}$ during the two studied seasons. Nitrogen $(\mathrm{N})$ content was increased with $1 \%$ PPFM spraying in first season and with $3 \%$ in second season. However, no significant effect to PPFM spraying was detected on phosphorus $(P)$ content in both studied seasons. Moreover, potassium (K) \% values showed that spraying of PPFM at 1,2 , and $3 \%$ greatly increased $K \%$ of rosemary plant than in the control. Higher values of $\mathrm{K} \%$ were obtained with $2 \%$ PPFM bacteria spraying in first season, and with 3\% PPFM in second season.

Table 4. Effect of PPFM bacteria spraying as a bio-stimulant on $\mathrm{N}, \mathrm{P}$ and $\mathrm{K}$ contents (as percentages in leaves) in rosemary (Rosmarinus officinalis L.) plant, during 2018 and 2019 seasons.

\begin{tabular}{|c|c|c|c|c|c|c|}
\hline \multirow[b]{2}{*}{ Treatments } & \multicolumn{2}{|c|}{$\mathrm{N} \%$} & \multicolumn{2}{|c|}{ P \% } & \multicolumn{2}{|c|}{$\mathrm{K} \%$} \\
\hline & $\begin{array}{c}2018 \\
\text { season }\end{array}$ & $\begin{array}{c}2019 \\
\text { season }\end{array}$ & $\begin{array}{c}2018 \\
\text { season }\end{array}$ & $\begin{array}{c}2019 \\
\text { season }\end{array}$ & $\begin{array}{c}2018 \\
\text { season }\end{array}$ & $\begin{array}{c}2019 \\
\text { season }\end{array}$ \\
\hline Control & $1.45 \mathrm{~b}$ & $1.99 \mathrm{a}$ & $0.21 \mathrm{a}$ & $0.23 \mathrm{a}$ & $1.52 \mathrm{~b}$ & $1.80 \mathrm{a}$ \\
\hline $1 \%$ PPFM & $1.66 \mathrm{a}$ & $1.84 \mathrm{~b}$ & $0.21 \mathrm{a}$ & $0.24 \mathrm{a}$ & $1.67 \mathrm{a}$ & $1.79 \mathrm{a}$ \\
\hline $2 \%$ PPFM & $1.54 a b$ & $1.74 \mathrm{c}$ & $0.23 \mathrm{a}$ & $0.25 \mathrm{a}$ & $1.71 \mathrm{a}$ & $1.67 \mathrm{~b}$ \\
\hline $3 \%$ PPFM & $1.55 \mathrm{ab}$ & $2.00 \mathrm{a}$ & $0.27 \mathrm{a}$ & $0.24 \mathrm{a}$ & $1.56 \mathrm{~b}$ & $1.83 \mathrm{a}$ \\
\hline
\end{tabular}

- PPFM = Pink Pigmented Facultative Methylotrophic bacteria.

- Values followed by the same letter (s) are not significantly different at $5 \%$ level. (Waller and Duncan, 1969).

In this respect, similar findings were found out via Madhaiyan et al (2012) who located that inoculation with PPFM stepped forward nutrient uptake of tomato, pepper and rice vegetation when in comparison to non-inoculated plants. Also, Ombase et al (2003) indicated that foliar sprays of PPFM gave evident will increase in $\mathrm{N}, \mathrm{P}$ and $\mathrm{K}$ uptake in groundnut plant. However, a super impact to PPFM micro organism on phosphate solubilization and uptear by means of the plant and therefore recorded high degree of $P$ on plant leaves was located by means of Jayashree et al (2011). In another observe with the aid of Holland and Polacco (1994) in which they stated that PPFMs are involved in the $\mathrm{N}$ metabolism of colonized plants with the aid of production of urease enzyme and this finding could explaine the splendid impact on $\mathrm{N}$ content because of PPFM applied inside the present study on rosemary plant.

\section{3- Chemical constituents}

Data in Tables (5 and 6) show the effect of PPFM bacteria spraying on total carbohydrates, $\mathrm{C} / \mathrm{N}$ ratio, nitrate and nitrite contents and volatile oil content of rosemary plant. Evident increases in total carbohydrates were observed due to PPFM bacteria spraying at 1, 2 and $3 \%$ compared with the control in the first season. In this regard, 1\% concentration of PPFM was superior than 2 or $3 \%$. concentrations in increasing total carbohydrates of rosemary plant. Values of $\mathrm{C} / \mathrm{N}$ ratio demonstrated that the highest value in first season (13.24) was recorded by $3 \%$ PPFM bacteria spraying, whereas in the second season (9.23) it was recorded by $1 \%$ PPFM when compared to the remaining treatments. On the other hand in second season, it was noticed that $3 \%$ PPFM treatment recorded less $\mathrm{C} / \mathrm{N}$ ratio values (6.62) than in the control (8.27). 
The beneficial effect to PPFM bacteria spraying was clearly obtained with nitrate and nitrite accumulation in rosemary herb in both studied seasons. Untreated rosemary herb contained 92.20 and 118.6 ppm of nitrate in first and second season, respectively, whereas it decreased to 72.39 and 79.3 ppm with $3 \%$ PPFM spraying. The other PPFM treatments recorded medium values of nitrate content and still less than control. Additionally, an evident decrease in nitrite content in rosemary herb with all PPFM bacteria spraying than control was obtained, where, it decreased from $7.88 \mathrm{ppm}$ in control to 1.61 ppm in 3\% PPFM in first season. In second season, nitrite content decreased from $8.96 \mathrm{ppm}$ in control to $5.37 \mathrm{ppm}$ in $3 \%$ PPFM bacteria spraying.

Table 5. Effect of PPFM bacteria spraying as a biostimulant on total carbohydrates and $\mathrm{C} / \mathrm{N}$ ratio in rosemary (Rosmarinus officinalis L.) plant, during 2018 and 2019 seasons.

\begin{tabular}{|l|c|c|c|c|}
\hline \multirow{2}{*}{ Treatments } & \multicolumn{2}{|c|}{$\begin{array}{c}\text { Total } \\
\text { Carbohydrates \% }\end{array}$} & \multicolumn{2}{c|}{ C/N ratio } \\
\cline { 2 - 5 } & $\mathbf{2 0 1 8}$ & $\mathbf{2 0 1 9}$ & $\mathbf{2 0 1 8}$ & $\mathbf{2 0 1 9}$ \\
& season & season & season & season \\
\hline Control & $17.60 \mathrm{c}$ & $16.46 \mathrm{ab}$ & $12.13 \mathrm{c}$ & $8.27 \mathrm{~b}$ \\
$1 \%$ PPFM & $21.08 \mathrm{a}$ & $16.46 \mathrm{a}$ & $12.70 \mathrm{~b}$ & $9.23 \mathrm{a}$ \\
$2 \%$ PPFM & $19.44 \mathrm{~b}$ & $15.80 \mathrm{~b}$ & $12.62 \mathrm{bc}$ & $7.25 \mathrm{~b}$ \\
$3 \%$ PPFM & $20.52 \mathrm{a}$ & $16.33 \mathrm{ab}$ & $13.24 \mathrm{a}$ & $6.62 \mathrm{~d}$ \\
\hline
\end{tabular}

- PPFM = Pink Pigmented Facultative Methylotrophic bacteria.

- Values followed by the same letter (s) are not significantly different at $5 \%$ level. (Waller and Duncan, 1969).
Significant differences were clear either between different treatments or between the applied treatments and control (refer to table 6 for details). The great effect to PPFM spraying as a bio-stimulant to the increase of volatile oil \% of rosemary plant is considered one of the most important findings in this research work.

Clearly, volatile oil \% was greatly affected with all applied spraying treatments of PPFM compared to control in both studied seasons. The highest values of volatile oil $\%$ ( 0.60 and $0.70 \%)$ were recorded with $3 \%$ PPFM in first and second season, respectively. Next, $2 \%$ PPFM recorded the second order of volatile oil followed by $1 \%$ PPFM treatment.

The obtained records are in concord with those located via Cervantes-Martinez et al (2004) who established that the inoculation of PPFMs was observed to increase the photosynthetic pastime and consequently acquire total carbohydrates with the aid of improving the variety of stomata, chlorophyll concentration and malic acid content material of the plant. It is well called described by means of Roozeboom, (2011) that nitrate $\left(\mathrm{NO}_{3}\right)$ and nitrite $\left(\mathrm{NO}_{2}\right)$ accumulation in plant life is affected by some factors, e.g. immoderate use of nitrogen fertilizer, nutrient deficiencies ( $\mathrm{P}, \mathrm{K}$ and $\mathrm{Mg}$ ), environmental factors (drought, sunlight, frost, hail, diseases or temperature) and plant elements consisting of plant type (medicinal flora, vegetables, forage). So, the application of PPFM as a bio-stimulant can solve many troubles in natural and smooth agriculture through reducing the degrees of $\mathrm{NO}_{3}$ and $\mathrm{NO}_{2}$ that's considered critical and critical in medicinal herb consumption as they are regarded to be directly consumed with the aid of human beings both fresh and dry.

Table 6. Effect of PPFM bacteria spraying as a bio-stimulant on $\mathrm{NO}_{3}$ and $\mathrm{NO}_{2}$ contents and on percentage of volatile oil in rosemary (Rosmarinus officinalis L.) plant, during 2018 and 2019 seasons.

\begin{tabular}{|c|c|c|c|c|c|c|}
\hline \multirow[b]{2}{*}{ Treatments } & \multicolumn{2}{|c|}{$\mathrm{NO}_{3}(\mathrm{ppm})$} & \multicolumn{2}{|c|}{$\mathrm{NO}_{2}$ (ppm) } & \multicolumn{2}{|c|}{ Volatile oil \% } \\
\hline & $\begin{array}{c}2018 \\
\text { season }\end{array}$ & $\begin{array}{c}2019 \\
\text { season }\end{array}$ & $\begin{array}{c}2018 \\
\text { season }\end{array}$ & $\begin{array}{c}2019 \\
\text { season }\end{array}$ & $\begin{array}{c}2018 \\
\text { season }\end{array}$ & $\begin{array}{c}2019 \\
\text { season }\end{array}$ \\
\hline Control & $92.20 \mathrm{a}$ & $118.6 \mathrm{a}$ & $7.88 \mathrm{a}$ & $8.96 \mathrm{a}$ & $0.12 \mathrm{~d}$ & $0.13 \mathrm{~d}$ \\
\hline $1 \%$ PPFM & $80.44 \mathrm{~b}$ & $95.7 \mathrm{~b}$ & $4.30 \mathrm{~b}$ & $8.24 \mathrm{a}$ & $0.20 \mathrm{c}$ & $0.30 \mathrm{c}$ \\
\hline $2 \%$ PPFM & $76.73 \mathrm{c}$ & $82.2 \mathrm{c}$ & $3.76 \mathrm{~b}$ & $5.55 \mathrm{~b}$ & $0.40 \mathrm{~b}$ & $0.40 \mathrm{~b}$ \\
\hline $3 \%$ PPFM & $72.39 \mathrm{~d}$ & $79.3 d$ & $1.61 \mathrm{c}$ & 5.37 b & $0.60 \mathrm{a}$ & $0.70 \mathrm{a}$ \\
\hline
\end{tabular}

- PPFM = Pink Pigmented Facultative Methylotrophic bacteria.

- Values followed by the same letter (s) are not significantly different at $5 \%$ level. (Waller and Duncan, 1969). 
Impact of pink pigmented facultative methylotrophic bacteria as a bio-stimulant on growth, 259 herb yield and volatile oil attributes of rosemary (Rosmarinus officinalis $I$.) plant

\section{2- Volatile oil components}

It is clear from data in Table (7) that PPFM bacteria spraying on rosemary plant greatly affected volatile oil components during the two studied seasons. The main components were observed in rosemary volatile oil were Camphor, Eucalyptol, Verbenone, Borneol. Pinene, Pinanone. Bornyl acetate and Camphene.
All applied PPFM bacteria spraying at 1, 2, 3\% recorded high values \% of volatile oil components than control, where control recorded 83.30 and $85.25 \%$ in first and second season, respectively, whereas the applied treatments as a general view recorded 95.82 and 94.60 for the two studied seasons.

Table 7. Effect of PPFM bacteria spraying as a bio-stimulant on volatile oil components in rosemary (Rosmarinus officinalis L.) plant, during 2018 and 2019 seasons.

\begin{tabular}{|c|c|c|c|c|c|c|c|c|}
\hline \multirow[b]{2}{*}{$\begin{array}{l}\text { Volatile Oil } \\
\text { Components }\end{array}$} & \multicolumn{4}{|c|}{ First season } & \multicolumn{4}{|c|}{ Second season } \\
\hline & control & $\begin{array}{c}1 \% \\
\text { PPFM }\end{array}$ & $\begin{array}{c}2 \% \\
\text { PPFM }\end{array}$ & $\begin{array}{c}3 \% \\
\text { PPFM }\end{array}$ & control & $\begin{array}{c}1 \% \\
\text { PPFM }\end{array}$ & $\begin{array}{c}2 \% \\
\text { PPFM }\end{array}$ & $\begin{array}{l}3 \% \\
\text { PPFM }\end{array}$ \\
\hline$\alpha$-Pinene & 5.00 & 8.78 & 7.25 & 6.14 & 5.31 & 7.25 & 7.77 & 8.02 \\
\hline Camphene & 2.59 & 3.00 & 3.43 & 3.16 & 2.01 & 3.43 & 2.64 & 3.06 \\
\hline Thuja-2,4(10)-diene & 0.88 & 1.00 & 1.25 & 1.14 & 1.18 & 1.25 & 0.88 & 0.94 \\
\hline$\beta$-Pinene & 1.23 & 1.09 & 1.18 & 1.20 & 1.00 & 1.18 & 0.65 & 0.80 \\
\hline$\beta$-Myrcene & 0.72 & 1.83 & 1.06 & 1.40 & 0.99 & 1.06 & 0.72 & 1.03 \\
\hline Delta 3-Carene & 0.90 & 1.31 & 1.47 & 1.24 & 0.90 & 1.47 & 0.87 & 0.94 \\
\hline p-Cymene & 1.02 & 1.28 & 1.30 & 1.00 & 1.10 & 1.20 & 1.80 & 0.98 \\
\hline D-Limonene & 2.34 & 2.34 & 3.98 & 3.03 & 3.03 & 3.48 & 3.01 & 3.42 \\
\hline Eucalyptol (1,8-Cineole) & 10.8 & 9.91 & 8.95 & 8.70 & 8.36 & 9.09 & 9.5 & 9.01 \\
\hline$\alpha$-Terpinolene & 0.90 & 0.97 & 1.20 & 1.00 & 0.80 & 1.20 & 1.20 & 1.20 \\
\hline Linalool & 5.17 & 6.26 & 6.30 & 6.74 & 6.08 & 6.30 & 6.48 & 6.10 \\
\hline chrysanthenone & 0.80 & 1.01 & 1.09 & 1.28 & 1.80 & 1.09 & 0.74 & 1.00 \\
\hline Camphor & 13.12 & 14.55 & 15.45 & 15.49 & 14.43 & 15.45 & 15.70 & 16.46 \\
\hline trans-3-Pinanone & 0.99 & 0.83 & 0.88 & 1.31 & 0.89 & 0.88 & 0.88 & 1.01 \\
\hline endo-Borneol & 7.27 & 8.71 & 8.32 & 8.00 & 7.00 & 8.32 & 8.35 & 7.99 \\
\hline 3-Pinanone, cis & 3.64 & 3.17 & 3.21 & 3.04 & 3.00 & 3.21 & 3.44 & 3.16 \\
\hline 4-Terpineol & 1.37 & 1.19 & 1.24 & 1.23 & 1.28 & 1.24 & 1.27 & 1.23 \\
\hline$\alpha$-Terpineol & 2.01 & 3.08 & 3.51 & 2.42 & 2.83 & 3.51 & 3.51 & 3.29 \\
\hline Nopol & 2.11 & 2.14 & 2.16 & 2.14 & 2.09 & 2.16 & 2.14 & 2.13 \\
\hline I-Verbenone & 7.67 & 8.56 & 8.72 & 8.04 & 7.53 & 8.22 & 7.70 & 8.33 \\
\hline p-Menth-2-en-7-ol, trans & 2.41 & 1.92 & 2.03 & 2.18 & 2.76 & 2.03 & 2.35 & 2.34 \\
\hline p-Menth-2-en-7-ol, cis- & 2.06 & 3.27 & 3.34 & 3.84 & 2.22 & 3.34 & 3.38 & 3.00 \\
\hline L-Bornyl acetate & 3.62 & 3.63 & 3.78 & 3.50 & 3.47 & 3.78 & 3.18 & 3.65 \\
\hline Caryophyllene & 2.52 & 2.17 & 2.35 & 2.94 & 2.74 & 2.35 & 1.98 & 2.18 \\
\hline Caryophyllene oxide & 1.16 & 0.96 & 1.07 & 1.63 & 1.43 & 1.07 & 1.08 & 1.06 \\
\hline Geranyl acetone & 1.00 & 1.20 & 1.30 & 1.23 & 1.02 & 1.08 & 1.20 & 1.20 \\
\hline Total & 83.30 & 94.16 & 95.82 & 93.02 & 85.25 & 94.64 & 92.42 & 93.53 \\
\hline
\end{tabular}

- PPFM = Pink Pigmented Facultative Methylotrophic bacteria.

The highest values of Camphor (16.46\%) were recorded by $3 \%$ PPFM in second season, whereas untreated rosemary plant recorded higher values of both Eucalyptol and Pinanone than treated plants in first season. Additionally, the highest values of Verbenone $(8.72 \%)$ was recorded $2 \%$ PPFM in first season, Borneol (8.71\%) and Pinene (8.78\%) with $1 \%$ PPFM in first season. Regarding Bornyl acetate and Camphene the higher values were recorded by $1 \%$ and $2 \%$ PPFM bacteria spraying. The stimulant effect to PPFM bacteria on volatile oil $\%$ and volatile oil components could by explained by the synergestic effect and producing plant growth regulators which enhancing plant growth and improve the production of volatile oil content and increase the level of active substances. 
Also, the present study data on the enhanced effect to PPFM bacteria, on Volatile oil contents and percentage are similar to those found by Abdelaziz et al (2007) on rosemary, Mahfouz and SharafEldin (2007) on fennel, El-Hadi et al (2009) on mentha, Ordookhani et al (2011) on sweet basil and Khalesro et al (2012) on anis.

Finally, it could be recommended to apply PPFM bacteria as a foliar spray on rosemary plant to improve both quantity and quality through many manifested advantages especially increasing volatile oil $\%$ and volatile oil fractions the percent of active ingredients reducing $\mathrm{NO}_{3}$ and $\mathrm{NO}_{2}$ levels.

\section{REFERENCES}

Abdelaziz M., Pokluda R. and Abdelwahab M., 2007. Influence of compost, microorganisms and NPK fertilizer upon growth, chemical composition and essential oil production of Rosmarinus officinalis L. Notulae Botanicae, Horti Agrobotanici, Cluj Napoca, 35(1), 86-90.

A.O.A.C. 2005. Official methods of analysis of the association of official analytical chemists, $12^{\text {th }}$ edition.

A.O.A.C. 2012. Official Methods of Analysis of AOAC International.19th ed. Gaithersburg, MD, USA, Association of Analytical Communities.

Basile D.V., Basile M.R., Li Q.Y. and Corpe W.A. 1985. Vitamin B12-stimulated growth and development of Jungermannia leiantha Grolle and Gymnocolea inlata Dum. (Hepaticae). Bryologist $88,77-81$.

Bringham F.T. 1982. Methods of Soil Analysis (Ed. ) Part 2, Agronomy, 9 431-447.

Charles D.J. and Simon J.E. 1990. Comparison of extraction methods for the rapid determination of essential oil content and composition of basil (Ocimum spp.). J. Amer. Soc. Hort. Sci., 115(3), 458-462.

Cervantez-Martinez J., Lopez-Diaz S. and Rodriguez-Gary B. 2004. Detection of the effects of Methylobacterium in Agave tequilana Weber var. azul by laser-induced fluorescence. Plant Sci., 166, 889-892.

Corpe W.A. 1985. A method for detecting methylotrophic bacteria on solid surfaces. J. Microbiol. Methods 3, 215-221.

Corpe W.A. and Rheem S. 1989. Ecology of the methylotrophic bacteria on living leaf surfaces. FEMS Microbiol. Ecol. 62, 243-249.
Cuvelier M.E., Richard H. and Berset C. 1996. Antioxidative activity and phenoli composition of pilot-plant and commercial extracts of sage and rosemary. J. Am. Oil Chem. Soc. 73, 645-652.

Doronina N.V., Ivanova E.G. and Trotsenko I. 2002. New evidence for the ability of methylobacteria and methanotrophs to synthesize auxins. Microbiology 71, 116-118.

El-Hadi N.I., El-Ala K.A. and El-Azim M.A. 2009. Response of some Mentha species to plant growth promoting bacteria (PGPB) isolated from soil rhizosphere. Australian J. Basic and Applied Sci., 3(4), 4437-4448.

Gashti A.H., Rashidi V., Vishkaei M.N., Esfahani M. and Farahvash F. 2014. Effect of foliar application of Methylobacterium and Methanol on growth and Yield of peanut (Arachise hypogaea L.cv. $\mathrm{NC}_{2}$ ). Advances in Environmental Biology, 8(21), 1256-1262.

Guebel D.V., Nudel B.C. and Giuletti A.M. 1991. A simple and rapid micro-Kjeldahl method for total nitrogen analysis. Biotechnol. Tech., 5(6), 427-430.

Habtemariam S. 2016. The therapeutic potential of rosemary (Rosmarinus officinalis) diterpenes for Alzheimer's disease. Evid. Based Complement. Altern. Med., http://dx.doi.org. 10.1155/2016/2680409.

Hirano S.S. and Upper C.D. 1991. Bacterial community dynamics. In: Microbial Ecology of Leaves (Andrew, J.H. and Hirano, S.S., Eds.), Springer-Verlag, New York., USA. pp. 271-294.

Holland M.A. 1997. Methylobacterium and Plants. Recent Res. Dev. Plant Physiol. 1, 207-213.

Holland M.A. and Polacco J.C. 1994. PPFMs and other covert contaminants: Is there more to plant physiology than just plant? Annu. Rev. Plant Physiol. Plant Mol. Biol. 45, 197- 209.

Holland M.A., Long R.I.G. and Polacco J.C. 2002. Methylobacterium spp.: phylloplane bacteria involved in cross-talk with the plant host. In: Lindow, S.E., Hecht-Poinar E.I. and Elliot V.J. (Eds). Phyllosphere Microbiology. APS, St., Paul Minn., USA. pp. 125-135.

Jayashree S., Vadivukkarasi P., Anand K., Kato, Y. and Seshadri S. 2011. Evaluation of pinkpigmented facultative methylotrophic bacteria for phosphate solubilization. Archives of Microbiology; 193, 543-552.

Kayashima T. and Matsubara K. 2012. Antiangiogenic effect of carnosic acid and carnosol, neuroprotective compounds in rosemary leaves. Biosci. Biotechnol. Biochem., 76, 115-119. 
Impact of pink pigmented facultative methylotrophic bacteria as a bio-stimulant on growth, 261 herb yield and volatile oil attributes of rosemary (Rosmarinus officinalis I.) plant

Khalesro S., Ghalavand A., Sefidkon F. and Asgharzadeh A. 2012. The effect of biological and organic inputs on quantity and quality of essential oil and some elements content of anise (Pimpinella anisum L.). Iranian J. Medicinal and Aromatic Plants; 27(4), 551-560.

Koenig R.L., Morris R.O. and Polacco J.C. 2002. tRNA is the source of low-level trans-zeatin production in Methylobacterium spp. J. Bacteriol. 184, 1832-1842.

Lee H.S., Choi M., Chung K.Y. and Young T.M. 2006. Physiological enhancement of early growth of riceseedlings (S.A. Oryza sativa L.) by production ofphytohormone of N2-fixing methylotrophic isolates. Bio. Ferti. Soils, 42, 402-408.

Madhaiyan M., Poonguzhali S., Senthilkumar M., Lee J.S. and Lee K.C. 2012. Methylobacterium gossipiicola sp. nov., a pink pigmented, facultatively methylotrophic bacterium isolated from the cotton phyllosphere. Int. J. of Systematic and Evolutionary Microbiology, 62, 162-167.

Madhaiyan M., Poonguzhali S., Sundram S.P. and Sa T. 2006. A new insight to foliar applied methanol influencing phylloplane methylotrophic dynamics and growth promotion of cotton (Gossyoium hirsutum L.) and sugarcane (Saccharum officinarum L.). Environ. Exp. Bot., 57, 168-176.

Mahfouz S.A. and Sharaf-Eldin M.A. 2007. Effect of mineral vs. biofertilizer on growth, yield and volatile oil content of fennel (Foeniculum vulgare Mill.). Int. Agrophysics, 21, 361-366.

Meena K.K., Kumar M. and Kalyuzhnaya M.G., 2012. Epiphytic pink-pigmented methylotrophic bacteria enhance germination and seedling growth of wheat (Triticum aestivum) by producing phytohormone. Antonie van Leeuwenhoek., 101, 777-786.

Mizrahi I., Juarez M.A. and Bandoni A.L. 1991. The essential oil of Rosmarinus officinalis growing in Argentina. J. Essent. Oil Res. 3, 11-15.

Mizuno M., Yurimoto H., Iguchi H., Tani A. and Sakai Y. 2013. Dominant colonization and inheritance of Methylobacterium species strain OR01 on Perilla plants. Bioscience Biotechnology and Biochemistry. 77, 1533-1538.

Nadali I., Paknejad F., Moradi F., Vazan S., Tookalo M., Al-Ahmad M.J. and Pazoki A. 2010. Effects of methanol on sugar beet (Beta vulgaris). Australian J. of Crop Sci., 4(6), 398401.
Nieto G., Bañon S. and Garrido M.D. 2012. Incorporation of thyme leaves in the diet of pregnant and lactating ewes: Effect on the fatty acid profile of lamb. Small Rumin. Res. 105, 140-147.

Novak J., Jan L., Friedrich P. and Chlodwig M.F. 2002. Essential oil compounds in a historical sample of marjoram (Origanum majorana L., Lamiaceae). Flavour and Fragrance J., 17, 175180.

Ochsner A.M., Sonntag F., Buchhaupt M., Schrader J. and Vorholt J.A. 2015. Methylobacterium extorquens: methylotrophy and biotechnological applications. Applied Microbiology and Biotechnology, 99, 517-534.

Ombase A.R., Andsule R.N. and Amrutsagar V.M. 2003. Influence of foliar spray of methanol on growth, nutrient uptake and yield of summer groundnut. J. Maharashtra Agric. Univ., 28(3), 262-265.

Ordookhani K., Sharafzadeh S. and Zare M. 2011. Influence of PGPR on growth, essential oil and nutrients uptake of sweet basil. Advances in Environmental Biology., 5(4), 672-677.

Pintore G., Usai M., Bradesi P., Juliano C., Boatto G., Tomi F. and Chessa, M. 2002. Chemical composition and antimicrobial activity of Rosmarinus officinalis $L$. oils from Sardinia and Corsica. Flavour and Fragrance J. 17 (1), 15-19.

Raja D., Sivasankari B. and Thilagavathy D. 2008. Bioefficacy of Methylobacteriurn spp. isolated from various leaf samples on the growth performance of black gram, Vigna mungo $L$. walp. J. of Current Sci., 12, 735-740.

Raškovic' A., Milanovi ' I., Pavlovic N., C' ebovic' T., Vukmirovic' S. and Mikov M. 2014. Antioxidant activity of rosemary (Rosmarinus officinalis L.) essential oil and its hepatoprotective potential. BMC Complement. Altern. Med., 14(225), 1-9.

Roozeboom K. 2011 Nitrate Toxicity. Kansas State University Agricultural Experiment Station and tive Extension Service.

Slamenova D., Kuboskova K., Horvathova E. and Robichova S. 2002. Rosemary stimulated reduction of DNA strand breaks and FPG-sensitive sites in mammalian cells treated with $\mathrm{H}_{2} \mathrm{O}_{2} \mathrm{Or}$ visible light-excited. Methylene Blue Cancer Lett., 177, 145-153.

Snedecor G.W. and Cochran W.G. 1990. Statistical Methods. $11^{\text {th }}$ Ed. lowa State College Press. Ames, lowa, U.S.A. pp. 369-373. 
Socaci S.A., Maria T., Carmen S. and Varban D.S. 2007. Comparitive study of Different Rosemary Essential oil. Bulletin USAMV-CN, 63, 591-595.

Sy A., Giraud E., Jourand P., Garcia N., Willems A., De L., Prin Y., Neyra M., Gillis M., Boivin M. and Dreyfus B. 2001. Methylotrophic Methylobacterium bacteria nodulate and $\boldsymbol{\phi} \times$ nitrogen in symbiosis with legumes. J. Bacteriol. 183, 214-220.

Tani A., Sahin N. and Kimbara K. 2012. Methylobacterium gnaphalii sp. nov., isolated from leaves of Gnaphalium spicatum. Int. J. of Systematic and Evolutionary Microbiology, 62, 2602-2607.
Wada M., Kido H., Ohyama K., Kishikawa N., Ohba Y., Kuroda N. and Naka S.K. 2004. Evaluation of quenching effects of non-water-soluble and water-soluble rosemary extracts against active oxygen species by chemiluminescent assay. Food Chemistry, 87, 261-267.

Waller R.A. and Duncan D.B. 1969. A Bayes rule for the symmetric multiple comparisons problem. Journal of the American Statistical Association, pp. 1484-1503. http://dx.doi.org/ 10.1080/01621459.1969.10501073, 


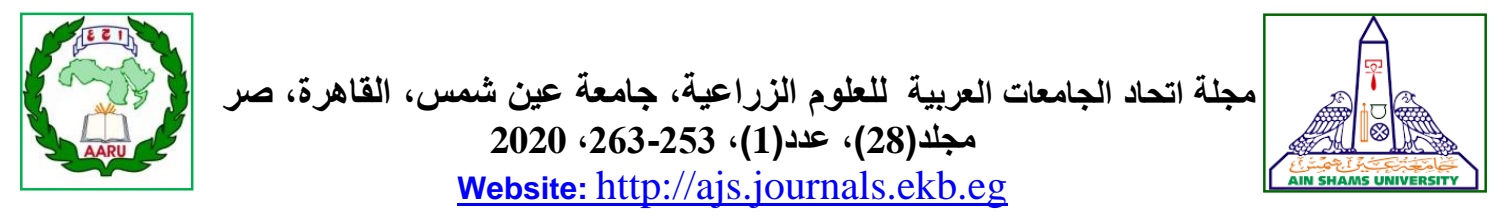

\section{تأثير البكتريا القرمزية مثيلية التفذية كمنشط حيوي على النمو وإنتاج العشب والزيت الطيار لنبات الحصالبان}

[18]

دعاء سليمان 1 - عبد العزيز محمد حسني 1 - أحمد نظمي عبد الحميد1" - منى عرفة محمد2 2

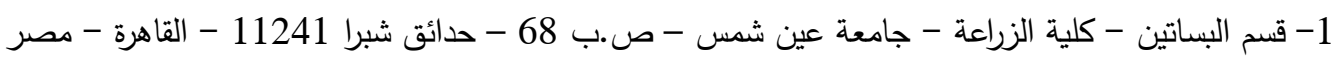

$$
\begin{aligned}
& \text { 2- شعبة البحوث الدوائية والصيدلية - المركز القومي للبحوث - الجيزة - القاهرة }
\end{aligned}
$$

*Corresponding author: nazmy604@yahoo.com

التأثير الأكثر أهمية لرش البكتريا القرمزية على نبات

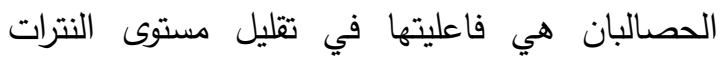

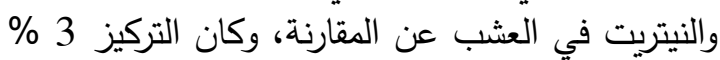

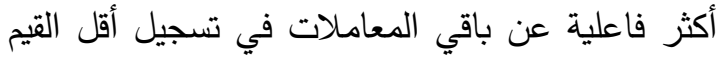
من النترات (72.39 جزء/مليون)، والنيتريت (1.61 فئسيت

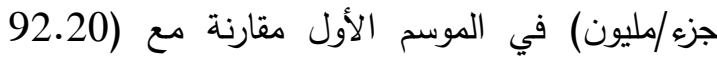
جزء/مليون للنترات)، (7.88 جزء/ (لمعن/ مليون للنيتريت)

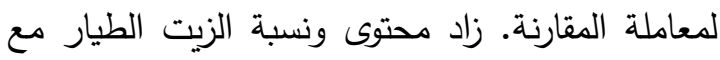

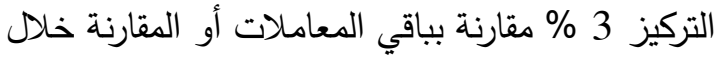

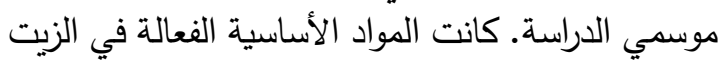

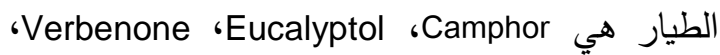
،Bornyl acetate 'Pinanone ‘Pinene 'Borneol Camphene تركيزاتها الثلاثة المستخدمة تتشيطاً واضحاً للمكونات المات الفعالة وزادت نسبتها مقارنة بالنباتات غير التهاتيات المرشوشة. وفي النهاية يمكن التوصية و الجزم بأن استخدام

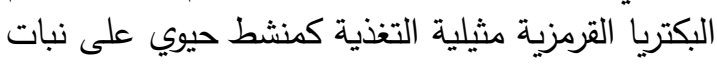
الحصالبان كان لله عدة مزايا خاصة تقليل مستوى النترات

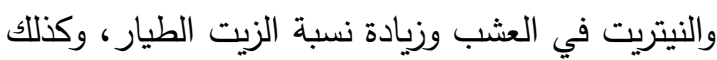
زيادة نسبة المواد الرئيسية في الزيت الطيار .

الكلمات المفتاحية: بكتريا قرمزية، نبات الروزماري، زيوت طيارة، حصالبان

\section{الموجــز}

درس تأثير رش البكتريا القرمزية كمنشط حيوي على العي النمو الخضري ومستوى العناصر الكبرى النتروجين والفوسفور والبوتاسيوم والمحتوى الكيماوي ونسبة الزيت النيت الكيتين الطيار وكذلك مكونات الزيت الطيار لنبات الحصالبان ولنيان

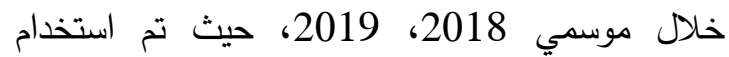

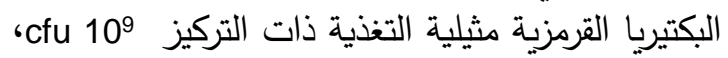

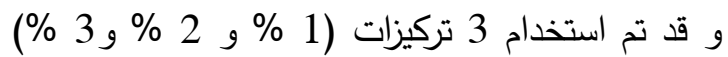
الي جانب معاملة المقارنة.ويمكن تلخيص أهم النتائج

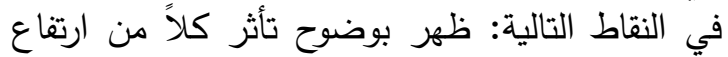

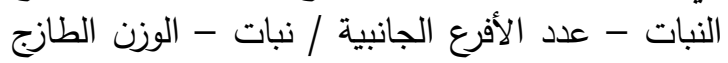

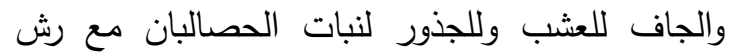

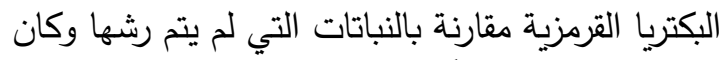

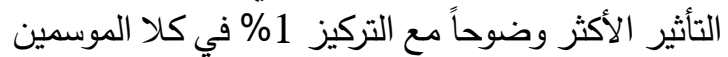
مقارنة بالتركيز 2\%، 3 \% \% زاد المحتوى من النتروجين والبوتاسيوم مع التركيز 1\% بالتركيز 3 \% بينما لم يكن هناد الك فروقاً معنوية على محتوى العشب من عنصر الفوسفور نتيجة

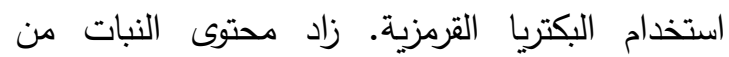

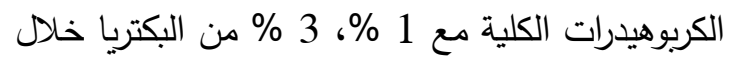
موسمي الدراسة بينما سجلت أعلى القيم من من نسبة البكتية الكربوهيدرات إلى النتروجين مع 3 \% من البكتيا القرمزية في الموسم الأول، 1 \% في الموسم الثاني. كان 